\title{
A pregação da virtude em Gonçalo Fernandes Trancoso
}

Geraldo Augusto Fernandes ${ }^{1}$

http://lattes.cnpq.br/3081836249489094

Enviado em: 11/08/2018

Aceito em: 09/12/2018

RESUMO: No século XVI, em Portugal, Gonçalo Fernandes Trancoso escreve seus Contos e Histórias de Proveito \& Exemplo com intenção pedagógico-moralizante, desiludido ao assistir à dissolução dos costumes trazida pelas conquistas ultramarinas. Vale-se de um recurso próprio do medievo os exemplos - para mostrar-se como paladino que luta pelos valores da Virtude. O objetivo desse artigo é analisar como o autor monta seus contos de pregação, analisando as técnicas narrativas utilizadas para mostrar como esses contos tornaram-se leitura prazerosa e edificante.

PALAVRAS-CHAVE: Virtude; doutrinação; exemplos; contos.

ABSTRACT: In the sixteenth century, in Portugal, Gonçalo Fernandes Trancoso writes his Contos e Histórias de Proveito \& Exemplo with pedagogical-moralizing intent, disillusioned at the dissolution of the customs brought by the overseas conquests. The author makes use of a resource of the medieval era - the exempla - to show himself as a champion that fights for the values of the Virtue. The purpose of this article is to analyze how the author mounts his preaching stories by analyzing the narrative techniques used to show how these stories have become a pleasurable and uplifting reading.

KEYWORDS: Virtue; preaching; exempla; tales.

\section{Apresentação}

O autor renascentista português Gonçalo Fernandes Trancoso, em sua obra Contos $e$ Histórias de Proveito \& Exemplo, procura pregar seu conceito de moral religiosa e social em narrativas com imagens que concebe sobre a Virtude. Assistindo ao novo comportamento dos portugueses, gananciosos e iludidos pelas riquezas trazidas das colônias conquistadas, Trancoso denuncia o apego ao mundo material e o abandono a que a nova sociedade relega os valores do espírito.

Através de uma forma inovadora em Portugal, o conto, Trancoso dará corpo à sua pregação moralizante, valendo-se de releituras de contos populares e outros advindos da tradição oriental, disseminados pelo intercâmbio cultural promovido pelos Descobrimentos.

Nossa proposta é desenvolver uma análise das suas histórias sob o ângulo restrito da estrutura. Para isso, propusemo-nos a dar uma visão geral comum aos contos, i. e, seguir os passos que marcam a estrutura das narrativas de Fernandes Trancoso e, dela, examinarmos como se desenvolve a mensagem.

\footnotetext{
1 Universidade Federal do Ceará, Doutor em Letras, Professor de Literatura Portuguesa. E-mail: geraldoaugust@uol.com.br
} 


\section{O conto português no século XVI. Gonçalo Fernandes Tran- coso e seu tempo: contexto histórico e motivações pessoais}

O conto, como gênero literário e com o significado que hoje se lhe atribui de narrativa curta, aparece somente no século XVI, tendo sido Gonçalo Fernandes Trancoso o primeiro contista em língua portuguesa, quando, em 1575, publica os seus Contos e Histórias de Proveito \& Exemplo (MOISÉS, 1967, p. 95). Embriões do gênero encontravam-se já nos livros de linhagens, em que, mescladas aos relatos genealógicos da realeza e da nobreza portuguesas, apareciam lendas e histórias, quase sempre de cunho maravilhoso e de origem vária, como a céltica ou a oriental, por exemplo. Além desses textos, registrem-se as espécies de contos que aparecem em textos bíblicos, na Bíblia. Também na obra anônima Horto do Esposo, do século XIV, os exemplos são o cerne do livro, com referências frequentes às autoridades, sempre com cunho moralizante ${ }^{2}$.

O que caracteriza a narrativa do conto (daí ter como estrutura uma curta extensão, se comparada ao romance ou à novela) é a ação dramática centrada no conflito, no "choque de duas ou mais personagens, ou de uma personagem com suas ambições e desejos contraditórios" (MOISÉS, 1967, p. 100).

É justamente a palavra conflito que nos interessa na análise da obra de Gonçalo Fernandes Trancoso. Nascido no início de um século de grande progresso em Portugal, devido aos resultados das navegações e consequentes Descobrimentos, Trancoso viveu numa sociedade que experimentava um estado de contradição. Atenhamo-nos a esse Portugal das conquistas ultramarinas e acompanhemos o quadro pintado por Nicolau Clenardo, quando, entre 1533 e 1538, permaneceu em terras lusitanas:

'Em Portugal, todos somos nobres' (...) Porque se pretende aparentar a vida de grandes senhores, não se ama o trabalho, qualquer actividade é considerada desprezível e daí que o Reino se não desenvolva, apresentando uma agricultura estagnada não possuindo indústrias e comprando os produtos que nos chegam nas caravelas (DIAS, 1998, p. 378).

Parece-nos que esse é o centro de contradição que marca a era dos Descobrimentos, quando, pelas riquezas que transitavam no reino, não deveria a sociedade portuguesa enfrentar a estagnação; ao invés de enriquecer, o que se verifica é uma sociedade cada vez mais empobrecida. O deslumbramento causado por aquelas riquezas advindas das terras coloniais, antes de trazer o progresso, não só material, mas também nas relações sociais mais justas, provocava, na verdade, a dissolução dos costumes. É essa dissolução que Gil Vicente, Sá de Miranda, Álvaro de Brito Pestana, Duarte da Gama, entre outros, e mais tarde Camões, vão transpor para seus poemas, sátiras e farsas, fazendo contundente e saudável denúncia através da Literatura. Nas palavras de Álvaro de Brito

'fez o tempo outra volta' - alterou-se a ordem, inverteram-se as hierarquias e, face ao desconcerto do mundo, um manto de nostalgia, de pesar e de tristeza vai baixando sobre os Portugueses: já estão longe os tempos em que tudo era prazer, gentileza, galanteria, em que danças e cantares alegravam o Reino (DIAS, 1998, p. 396).

\footnotetext{
${ }^{2}$ Ettore Finazzi-Agrò registra também como embrião do conto, as novelas de cavalaria, se separadas do todo, as diversas aventuras descritas nesse gênero. "poderíamos (...) nos perguntar se não seria possível definir, funcionalmente, como 'novelas' muitos dos capítulos dos romances de cavalaria, cuja autonomia é sublinhada frequentemente, para além do mais, por uma lição moral inserida no seu encerramento" (FINAZZI-AGRÒ, 1978, p. 85).
} 
No âmbito da religiosidade, mais forte ainda será o papel das Reformas por que passarão as ortodoxias e heterodoxias de então. Nas palavras de Alphonse Dupont, “o homem agora luta sozinho com seu destino do além” (LEBRUN 1991, p. 102). Adira-se à questão da Reforma Protestante e à sua reação, a Contrarreforma, o fato de que, nesse mesmo século, Trancoso foi contemporâneo à chegada da Inquisição ${ }^{3}$ em Portugal, o que acentua, para o homem de então, a insegurança que uma situação conflituosa deve provocar nas relações, em qualquer âmbito.

Quanto à experiência individual, o que marca definitivamente a vida de Trancoso é a perda que sofreu da esposa, de uma filha, um filho e um neto, em decorrência da Peste Grande que assolou Lisboa em 1569. Difícil dissociar de sua obra esse trágico acontecimento. O autor mesmo o marcará, no Prólogo à primeira edição dos Contos Proveitosos ${ }^{4}$, em carta dirigida à Rainha D. Catarina. À marca social, de um século em transformação, acrescenta-se a experiência que um evento de tão profundo significado pode trazer ao indivíduo. Não se admire que o traço característico de seus contos seja o de uma marcada pregação moralista aliada à fuga da cruel realidade, quando usa o "maravilhoso" como meio não só de criação literária, mas ainda de ensinamento. Impossível será, então, dissociar o narrador do autor.

\section{O erudito e o popular nos Contos e Histórias de Proveito \& Exem- plo}

Transpondo para a forma literária escrita o que a tradição popular oral ${ }^{5}$ contava, além de releituras de contos advindos do Oriente ou mesmo aqueles de base boccacciana ou italianizante, em Trancoso percebe-se a mescla do erudito e do popular ${ }^{6}$. Popular porque as fontes são essas mesmas, de procedência da criatividade e tradição do povo, que, sem podermos demarcar uma determinada origem ou datação precisas, disseminaram-se de cultura a cultura, de família a família, por gerações. Erudito porque essa fala, que é a do autor, refletida na escrita elaborada estilisticamente visa à sua significação referencial direta, adequada ao seu objeto. Será, uma vez que o autor é "dotado de autoridade", expressada de modo convincente, vigoroso, elegante, do ponto de vista do referente, cujo tratamento estilístico é orientado para a compreensão do referente (BAKHTIN, 1975, p. 464-65). E, mais do que isso, para compreensão do próprio receptor, pois esse, no século XVI, terá papel preponderante para as artes literárias, uma vez que "as artes antigas do trivium, que entraram pelo século XVI afora, pregavam insistentemente a adequação do discurso ao ouvinte" (MONGELLI, 2001, p. 36).

\footnotetext{
3 "Portugal tornava-se mais severo e restritivo na avaliação e apreensão de livros contendo sinais de heresia ou de desvios morais, conforme as regras tridentinas que se estabeleciam ao longo do século" (NEPOMUCENO, 2017a, p. 2).

${ }^{4}$ A obra de Gonçalo Fernandes Trancoso, aqui analisada, também é conhecida por Contos Proveitosos.

${ }^{5}$ Quanto ao tema, escreve Teófilo Braga: “... um grande número de contos persiste exclusivamente na transmissão oral do povo, que os transforma desde a primitiva concepção mítica até à simples aventura faceta ou à referência vaga de qualquer adágio; existe simultaneamente um outro grupo de contos conservados por via da redacção literária e escritos com uma certa intencionalidade moral ou artística (...). A universalidade dos contos populares na tradição oral não se pode explicar historicamente; este processo compete aos contos generalizados pela forma literária, cuja transmissão se estabelece quase de um modo cronológico e por documentos que subsistem." (BRAGA, 1994b, p. 18).

${ }^{6}$ Citando Boissier, Teófilo Braga comenta sobre a questão erudito versus popular: "Toda a grande arte começa por ser uma arte espontânea. Não nasce do povo nem de uma aristocracia, mas do concurso inteligente de ambos. Produzse ordinariamente quando uma classe superior da sociedade, ou um homem de génio se apossa da arte popular espontânea para aperfeiçoá-la.” E nas suas próprias palavras: “A literatura dos contos populares é o quadro da transmissão oral das tradições recebendo a nitidez e beleza estética da forma escrita.” (BRAGA, 1994b, p. 17).
} 


\section{Questões de estilo}

Não só pela opinião revelada por estudiosos de Gonçalo Fernandes Trancoso, tais como Massaud Moisés, Teófilo Braga ou João Palma-Ferreira, mas também pela evidência clara, pode-se considerar o autor renascentista português ainda "primitivo" quanto à escritura que empreende em seus contos. Esse primitivismo estilístico revela-se, principalmente, pelo uso excessivo, quase de forma ingênua, de orações coordenadas sindéticas e pela profusão de pronomes relativos.

Vossa Senhoria tem em casa muita gente que manter e alguma dela desnecessária e que podia bem despedir porque é escusada. E eu, como veador e que desejo o proveito de vossa fazenda, vendo que a mim toca o cuidado de prover nisto, fiz um rol de todos os que estão em casa, ordenando em duas colunas. (Conto VIII, Primeira Parte, p.29) ${ }^{7}$

Ainda quanto a esse aspecto "primitivista", devemos aludir às muitas ambiguidades que se registram, não só no corpo do conto, como também nas epígrafes. Vale um exemplo: "Que trata quanto vale a boa sogra e como, por indústria de uma sogra, esteve a nora bem casada com o filho que a aborrecia." (Conto I, Segunda Parte, p. 115) Aqui, além de se pensarem em duas sogras, pela colocação feita pelo autor, perguntar-se-á o leitor quem o filho aborreceria.

Se esse estilo ainda ingênuo tem mais a ver com a sistematização por que passava a língua portuguesa ${ }^{8}$, àquela época, em outros itens a forma escolhida parece ser proposital. O autor opta por recursos que o ajudarão a manter a coerência com seu objetivo de pregar. É assim que, como marcação de um uso comum, não só na literatura renascentista, mas que já vem da Idade Média, é o uso das epígrafes com que dá abertura, nas cimeiras, a cada narrativa. No entanto, se compararmos o modo como Trancoso dispõe seus "proêmios", e se nos ativermos a Boccaccio, que, no século XIV, também escreveu suas novelas de cunho moralista, mas impregnadas de realismo, assistindo a uma sociedade que sofria os males da peste de 1348, podemos verificar uma diferença de substância. Quando Boccaccio apenas resume o teor de sua novela, em que, nas entrelinhas percebem-se as intenções, Trancoso é direto: inicia a epígrafe com uma recomendação ou conselho e, em seguida, resume o teor do conto. Declara, por esse método, sua intenção sobre qual ensinamento quer passar ao leitor. Comparemos, a título de ilustração, os seguintes "proêmios" de Boccaccio:

O Senhor Ciappelletto engana a um santo frade fazendo-lhe uma falsa confissão; e morre. Em vida tendo sido um homem muito mau, é considerado santo após a morte, passando a ser chamado São Ciappelletto. (BOCCACCIO, 1979, p. 24)

e de Trancoso:

Que as filhas devem tomar o conselho de sua boa mãe e fazer seus mandamentos. Trata de uma que o não fez e a morte desastrada que houve. (Conto II, Primeira Parte, p. 6)

\footnotetext{
${ }^{7}$ Quando nos referirmos à obra de Trancoso, somente citaremos o número do conto, a parte e a página em que se encontra o trecho.

8 "A iniciação aos conhecimentos elementares da Gramática, nos Estudos Gerais, consistia em aprender a ler e a escrever em latim; quanto à língua portuguesa, embora convertida em língua oficial desde o reinado de D. Dinis, continuava a ser aprendida espontânea e naturalmente, fora dos bancos escolares, através da comunicação usual do dia a dia, assim permanecendo até o século XVI." (PAIVA, 1988, p. 10).
}

https://periodicos.unifap.br/index.php/letras Macapá, v. 8, n. 3, $2^{\circ}$ sem., 2018 
Menos que ilustração ou recorrência a um modelo antigo de montar o texto, as epígrafes servem ao autor como pretexto para disseminar suas ideias doutrinárias. Conforme discorre Luís André Nepomuceno,

\begin{abstract}
$\mathrm{Na}$ exposição de narrativas notoriamente moralizantes, Trancoso cuidou, ele mesmo, de evidenciar o caráter ético de cada um de seus personagens. Seria uma atitude quase doutrinária: na introdução de cada conto, põe à luz uma epígrafe, uma espécie de tabuada para servir de sumário do livro, tornando manifesto o seu ensejo didático, sem que o leitor possa se desviar das intenções do autor. Cristina Nobre reconhece que as tabuadas com intertítulos no começo de cada conto, sejam elas inclusões posteriores de editores, sejam inserções do próprio Trancoso, apresentam uma função descritiva, que repercute com determinadas consequências para o leitor, "que parte para uma primeira leitura do texto já com o conhecimento do princípio ético que ecoará em todo o conto", ou seja, "o sumário do argumento é encabeçado por uma interpretação antecipada do próprio conto" (NEPOMUCENO, 2017b, p. 214-215).
\end{abstract}

Ligados a essa questão, aparecem, como recurso recorrente em profusão, os provérbios. Todos os contos vêm carregados de máximas, ditos sentenciosos, apotegmas, o que não é de se admirar, já que essa intenção está no próprio título da obra ${ }^{9}$ e, também, nos motivos que levaram o autor português a escrever suas histórias. $\mathrm{Na}$ maioria dos contos, esses provérbios integram-se ao próprio texto, fluindo como parte ou decorrência da efabulação. Há casos, entretanto, em que o dito sentencioso está destacado em verso:

"Sempre é mau ser zombador,

E na barca pior.” (Conto V, Primeira Parte, p. 22)

Também sem exceção, os provérbios, ditos, máximas, estão registrados na epígrafe, ao longo da narrativa, e, com maior preponderância, no encerramento de cada uma delas. É um estilo próprio das fábulas que, no final, sempre nos passa a "moral da história". Aliada a esse encerramento com provérbios, observa-se uma marcação obsessiva - também isso como reminiscência dos escritos de cunho religioso e moral da Idade Média - das saudações a Deus, à Virgem Maria, aos santos e, sempre, o Amém, na última linha ${ }^{10}$. Essas alusões não poderiam ser diferentes, já que a intenção dos contos está no título mesmo da obra, como dissemos em nota: através dos exemplos, o autor pretende resgatar o culto pelas virtudes moral e religiosa.

Quanto às personagens ${ }^{11}$, o conto popular tem uma característica que Trancoso mantém. Em sua grande maioria, o autor não usa nomes próprios para designar suas figuras dramáticas. Essas aparecerão em maior número na Segunda e na Terceira Partes, cujos contos têm um cariz histórico ou, ainda, quando faz uma releitura de contos tradicionais e de outras culturas, trazendo a ação para a Península Ibérica. No primeiro caso, o de não

\footnotetext{
${ }^{9}$ Quando nos valemos de outro título pelo que se conhece sua obra, Contos Proveitosos, ou mesmo pelo uso de "Exemplos", no título do nome mais divulgado, o que nos remete ao conceito de histórias exemplares, que têm intenção didático-pedagógica.

${ }^{10}$ A questão do uso de provérbios, máximas, saudações ao divino e exemplos é bem marcada por Teófilo Braga quando afirma: "O nome de Exemplo especializou-se aos contos populares, que os pregadores intercalavam nos sermões da parenética medieval, explorando o gosto do vulgo, com esse instinto com que procederam os propagandistas budistas. O verna do mundo antigo, como notou Vico, usava essa linguagem pitoresca e franca, a vernácula, que exprimiu a prova legal da burguesia. Foi nessa linguagem que a Igreja empregou os Exemplos, quando quis dominar a alma popular.” (BRAGA, 1994b, p. 27).

11 “Qualquer personagem dos 'Contos' de Trancoso pode ser considerada um tipo, mas antes de o ser é, na realidade, uma ficção, ainda que fundamentada num modelo real. Como ficção existe mediante a estrutura que o autor lhe conferiu e manifesta-se pelo discurso com que se exprime.” (PALMA-FERREIRA, 1974, p. LV-LVI).
} 
nomear personagens e ater-se mais a seus atributos, percebe-se um denominador comum a todos os contos de cunho popular, com a clara intenção, segundo estudiosos, de tirar da realidade estereótipos com os quais possamos nos identificar. Já no segundo caso, parece-nos que a intenção é, na apropriação de contos de outras culturas, valorizar a cultura peninsular ascendente, dando-lhe traços de erudição, quando se refere a personagens que possam, até pelos nomes, identificar-se com os nobres daquela região. Luís André Nepomuceno registra que é difícil apreender

uma suma dos múltiplos universos díspares de Trancoso: personagens de muitas classes sociais, trabalhadores, plebeus, nobres, mulheres, feiticeiras, mercadores (talvez a classe mais representada), eclesiásticos e mesmo reis e rainhas desfilam pelo livro, denunciando um mundo de grande variedade social. (NEPOMUCENO, 2017b, p. 214).

$\mathrm{Na}$ sua grande maioria, os contos que escreve Trancoso têm cunho popularesco e, ao seu próprio estilo, ora o autor se serve dos provérbios para encaixar neles sua história, ora se apropria de um conto da tradição popular para nele encaixar seus ditos sentenciosos. Em ambos os casos, uma só intenção: a pregação pedagógico-moralizante. É dizer: servir-se daquilo que é comum ao leitor de então e nele embutir sua pregação moral, com o intuito premente de se resgatarem as virtudes, antes tão cultivadas ao longo da formação de Portugal e durante o medievo, ante um mundo agora em dissolução, na visão pessimista que tem Trancoso sobre seu tempo. Contudo, a criatividade de Gonçalo Fernandes, ainda que eivada de estilo um tanto arcaico e ingênuo - talvez explicado por ser um homem comum, sem formação erudita -, não se prende somente aos contos da tradição do povo. Cultivando um costume ainda próprio da Idade Média, vale-se o autor da reescritura de contos advindos de outras culturas, principalmente os de origem oriental e os de origem italiana. Os primeiros, reminiscências das Mil e Uma Noites, por exemplo, apesar de terem sido conhecidos na Europa apenas no século XVIII, deduzem-se terem sido trazidos pelo movimento das Cruzadas, quando a troca - e choque - de culturas é notória. Como exemplo, podemos citar os Contos XIV, da Primeira Parte (em que um senhor testa os filhos de um tabelião, o qual, por sua velhice, deverá ser substituído), e o Primeiro da Terceira Parte (em que, numa luta entre um Príncipe e seu vassalo, este vai se revelar o verdadeiro herdeiro do trono).

Quanto à apropriação de temas e histórias de origem italiana, importante observar dois fatos. Um de ocorrência em nível do espaço europeu, qual seja, a prevalência, no Renascimento, da cultura italiana sobre a francesa, principalmente pelo sucesso das novelas de Boccaccio, Petrarca, Straparola, Sanetti e outros. Outro de ocorrência regional, pois os intelectuais e filhos da nobreza portuguesa e castelã eram enviados à Itália para desenvolver seus estudos ${ }^{12}$. Trancoso, que, pelo que se deduz de sua biografia, não teve esse privilégio, soube com maestria cruzar o "tema boccacciano (...) com o tema do maravilhoso de impugnação provável do orientalismo” (PALMA-FERREIRA, 1974, p. 227).

Se, como temos afirmado, Gonçalo Trancoso inspira-se, em pleno Renascimento, ainda no estilo medieval de escritura - e de reescritura - de suas histórias, pode-se observar,

\footnotetext{
${ }^{12}$ Quanto a esse costume, a crítica italiana Jole Ruggieri nos dá um exemplo: "Nobili portoghesi era venuti in Italia alle lezioni del Poliziano, come J. Rodriguez de Sá de Menezes, nato dopo il 1460, che dall'Italia portò con sè per primo le nuove aspirazione del Rinascimento, conobbe la letteratura latina e greca, e primo affermò la necessità di una educazione superiore dell'aristocrazia..." (RUGGIERI, 1931, p. 215). Esse costume, como é sabido, entra o Quinhentos, e outro exemplo de amplo conhecimento na história literária é o retorno de Sá de Miranda, em 1527, levando para Portugal as novidades literárias da Itália, marcando, didaticamente, o início do Classicismo em terras lusitanas.
} 
também, em muitos contos, quando neles se impregna um ar de sociedade e costumes do medievo, as recorrências ao estilo cortesão de descrição das personagens e efabulação narrativa. O processo narrativo que utiliza no Conto II, da Segunda Parte, por exemplo, é característico da prosa medieval, em que o filho de um mercador vive várias aventuras no Oriente, mais especificamente em Fez. Com o intuito de aprender, nas viagens, o costume cavaleiresco, em África acaba por encontrar e comercializar - relíquias de santos e, além de conhecer, numa família moura, a filha de um rei de Inglaterra, com a qual se casará, tornar-se-á, ele próprio, ao cabo do conto, o futuro rei britânico. Também no Conto I, da Terceira Parte, a narração segue a trajetória do herói medieval, quando, pelas suas qualidades de cavaleiro, o vassalo revelar-se-á o verdadeiro Príncipe.

No que tange à descrição, as características dos heróis são carregadas de atributos próprios do estilo cortesão. A título de ilustração, observemos abaixo algumas descrições que resgatam as feições e atitudes próprias da "courtoisie":

E, demais de sua formosura e ser donzela, via nela uma discreção e saber que merecia ser mulher de um grande senhor (...). Esta que aqui tendes é vossa mulher, recebida à face da Igreja, como Deus manda, virtuosa, perfeita e boa, tal como, antes de agora, vos disse. (Conto I, Segunda Parte, pp. 123-124)

Numa cidade da Lusitânia havia um rico mercador que tinha um só filho de grande discreção e habilidade, muito ensinado nos bons costumes que o mancebo nobre deve ter, douto na língua latina e grega, dançante, músico, grande tangedor de todos os instrumentos e tecla, cavalgador e bom cavaleiro, destro em todo exercicio militar. (Conto II, Segunda Parte, p. 126)

Mais do que uma simples mostra de recorrência formal àqueles ideais do medievo, o que pretendemos destacar é que Trancoso se valeu de todos os recursos possíveis para enfatizar sua pregação moralizante, já que, como ressaltamos, seu objetivo primeiro é propor ao homem do século XVI o resgate das virtudes antigas. Virtudes que agora foram abandonadas pela revolução nos costumes, dos quais, na visão do autor português, preponderam os de caráter negativos à alma e ao relacionamento social.

Valendo-se de uma visão pessimista de seu tempo, dado à sua biografia, outra recorrência pontual em Trancoso é a prevalência do conceito de punição que sofrerão todos aqueles que transgridem os preceitos cristãos, como pregados pela Bíblia. Ao praticarem qualquer tipo de má ação e para o autor não importa o grau de maldade, uma vez que sua visão é maniqueísta: o Bem e o Mal são valores absolutos, portanto, não há graduação -, todos os transgressores sofrerão uma "punição hiperbolizada"13. Queremos usar essa adjetivação porque, realmente, o profundo sentimento de culpa a que o pecador assiste leva-o a um fim trágico que, quando não beira o cômico, é a própria sátira da tragicidade. Se São Tomás de Aquino "admite a necessidade de um erro para a justificação do pecado (para origem do pecado) e, portanto, para a sua expiação" (PALMA-FERREIRA, 1974, p. LXX), as personagens que agiram mal, tendo pecado consciente ou inconscientemente, devem pagar suas más ações de forma exemplar, edificante para o leitor, e de forma violenta. Entretanto, Gonçalo Trancoso não segue um padrão, em todos os seus contos. Ou a punição

\footnotetext{
13 “Assim sucede (...) nos 'Contos’ de Trancoso: as sanções, em vez de constituírem penas abstractas, são, muitas vezes, castigos temporais e materiais. O mesmo em relação aos prémios que se traduzem não num conceito muito espiritualista do proveito, mas num bem temporal que, quanto não é imediato, reverte em novo provérbio, desta feita radicado no fatalismo do comportamento misterioso da 'autoridade divina"' (PALMA-FERREIRA, 1974, p. LXIVLXV). Reforçando o que diz Palma-Ferreira, Ettore Finazzi-Agrò diz que "O Bem (...) contém já em si o próprio prémio como o Mal (ou o não-Bem) o próprio castigo, tratando-se num ou noutro caso de prémios e castigos imediatos, materiais". (FINNAZI-AGRÒ, 1978, p. 102).
} 
exagerada acontece pelo sentimento de culpa, mas a mão punitiva não foi a divina, ou a punição não acontece, mas é apenas sugerida.

Tenhamos alguns exemplos do que se discorreu no parágrafo anterior. No Conto V, da Primeira Parte, por ter zombado de um velho, que portava uma corcova muito grande, o zombeteiro, por ter feito a zombaria a um ancião - ícone do respeito a quem devemos ter, e em um local público, suprema heresia na visão do narrador moralizante - vai preso, é acometido de umas febres e acaba morrendo. Já no conto anterior a esse, o tema é o mesmo, mas a punição não acontece. Prevalece apenas a máxima ditada pelo narrador: "Não te rias de quem passa. E os que zombam dos feitos alheios, dão ocasião que lhes descubram os seus, porque é manha de açougue que, quem mal fala, mal ouve" (Conto VI, Primeira Parte, p. 20). No Conto VIII, da mesma Parte, situação semelhante. Por que quis despedir da casa do Arcebispo aqueles que não servem e, experimentando o arcebispado um ano de esterilidade, o Veador, pela sugestão dada ao prelado de que abrisse mão dos inúteis, envergonhou-se da proposta e da sabedoria do seu superior, caiu em doença e morreu fora do ofício e da casa.

Outros muitos exemplos desse tipo de castigo vão aparecendo nos contos: portugueses que traficavam morrem pelo pecado da corrupção (Conto I, da Segunda Parte); um moço que quer conquistar os bens materiais para suprir a família, mas, quando alcança seu objetivo, esquece-se dele; ou, no mesmo conto, aquele que quis ser pregador, mas, quando adquire posição no clero, torna-se soberbo. Ambos pagarão com sofrimento e com a morte pelos seus pecados (Conto V, Segunda Parte). Também nos contos de cunho maravilhoso, a punição hiperbólica vai aparecer: no suicídio das duas irmãs que fizeram mal a uma terceira irmã, escolhida para ser esposa do rei (Conto VII, Segunda Parte); na doença e morte da Rainha, além dos que com ela tramaram a troca do verdadeiro Príncipe por outro de linha sanguínea inferior (Conto I, Terceira Parte), e em outras histórias.

Nessas inúmeras recorrências às punições, eivadas do sentimento de culpa cristão, o mais interessante é o fato que aparece no Conto XV, da Primeira Parte. Nele, depois de vários sofrimentos por que passa, o herói chega ao último ato desesperador para atingir seu final feliz. Tenta o suicídio, como solução definitiva para seus dissabores. Vale-se Trancoso de um recurso até então pouco usado: o tragicômico. O sofredor desesperado sobe a um muro, joga-se e cai sobre um ancião que, naquele dia, depois de muita chuva, senta-se ao sol, debaixo do muro, para aquecer-se e conversar com conhecidos. A descrição de Trancoso é ímpar, se atentarmos ao registro do modo como, de uma ação trágica, não há como não fazer o leitor rir-se. Esse recurso ao cômico, explica Michel Zink, tem a ver com a questão do "contar o presente", em oposição ao culto do passado, próprio da Alta Idade Média. Essa maneira de retratar o contemporâneo estaria, para o autor francês, "na origem do romance moderno, romance de costumes ou romance psicológico", uma vez que "no fim da Idade Média (...) [a] novela, que retrata diretamente o presente, que o pinta, mesmo quando é cômica, com cores sombrias, ataca de maneira lúcida, até cínica" (ZINK, 2001, p. 85-86) esse mesmo presente.

No que tange às figuras de linguagem, apesar de não serem, ainda, de grande monta em Trancoso, nota-se, no conto a que nos referiremos agora, a discrição cortesã nas alusões ao relacionamento amoroso carnal.

$\mathrm{Na}$ poesia e romance cortesão, a expressão da sensualidade, por viva que seja, quase sempre lança sobre a revelação e a realização finais o véu da alusão, do eufemismo ou da metáfora. Tudo pode ser descrito, menos o ato sexual. Tudo pode ser nomeado, menos as pudenda (ZINK, 2001, p. 87).

A formação religiosa e a intenção moralizante não permitem a Gonçalo Fernandes as referências explícitas ao sexo. No Conto I, da Segunda Parte, as metáforas são várias, já que, para atingir seu objetivo - observe-se o paradoxo - a sogra (e até mesmo a nora) vai valer-se da astúcia feminina (bem ao gosto boccacciano) para revelar ao seu filho as virtudes 
de sua esposa. Enumeremos as figuras, além do paradoxo intencional do ardil da sogra, como ilustração:

Metáforas: "haver sua flor", por desvirginar (p. 120); "em que ele conheceu claro que ela era donzela quando ali veio", i. e., ela era virgem (p. 123)

Eufemismos: "filhas de Belial", por prostitutas (p. 121); "e a fez vestir e toucar àquele modo", ou seja, ao modo das prostitutas (p. 122)

Fora essas duas mostras, interessante observar que a sogra, para execução de seu plano, elegeu, como horário, "perto das Aves-Marias (que a velha escolheu estas [...] por boas)" (p. 127). É clara sua intenção de ressaltar a virtude e a virgindade da nora, aliadas à própria Virgem Maria, quando é lembrada pela hora em que a trama deve se desenrolar.

\section{A Posição do narrador}

Do quadro sinótico proposto pelos críticos norte-americanos Cleanth Brooks e Robert Penn Warren (MOISÉS, 1967, p. 107), ao observarmos aquele que narra a história, evidente é encontrarmos em Trancoso um "escritor (...) onisciente, [que] conta a história" (idem, p. 10). Um escritor analítico pode, é verdade, conforme Massaud Moisés, não ver tudo e todos. Mas Gonçalo Trancoso quase o consegue: ele é o texto, é ele que, baseado nos preceitos da literatura medieval, decide o destino de suas personagens, pela forma com que as manipula para disseminar sua pregação. E o recurso para torná-las todas suas marionetes é o da intervenção constante, não só nas ações dos actantes, como na própria narração, quando quer, aproveitando a "deixa", dissertar sobre a que veio ele, o narrador, com sua interrupção no fluxo narrativo.

Os apartes de que se serve Trancoso são decididamente declarados, i. e., o narrador faz questão de se mostrar, valendo-se de recursos variados, como se verá a seguir.

I. No conto de introdução à obra, em que usa o exemplo de um salteador que quer se corrigir e o ermitão que deve exercer o papel de auxiliar daquele desejo, o narrador mostrase como o próprio autor: “... também é necessário que eu corra minha memória, estude e, tomando a pena da mão, escreva o que aprendi, ouvi e li” (Conto I, Primeira Parte, p. 5) (Grifos nossos). O autor, por trás do narrador, mostra com que intenções se valeu da pena para escrever seus contos moralizantes. É conto-chave para entender como, nas suas histórias, se revela o narrador.

II. Vale-se Trancoso de um recurso ainda não completamente desenvolvido à época: o discurso indireto livre. Veja-se à página 27, no Conto VII, da Primeira Parte:

O qual se cumpriu e, ao assinar dela, el-Rei deu vinte cruzados, em ouro, ao mancebo, para o caminho. E lhe mandou que se fosse logo e que lhe escrevesse da terra; como chegará e que tais achará suas irmãs. (Grifos nossos).

Isso ainda parece primitivo, sem pretensão estilística, como produto de sintetização da ideia contida no parágrafo: a de agilizar a ação e sua consecução. Ao usar esse recurso, no entanto, percebe-se a importância que Trancoso dá ao elemento narrador, que deseja, através de suas personagens, pregar considerações morais, em outras palavras virtude.

III. Em todas as epígrafes, além de resumir o conto, o narrador revela-se, dando ao leitor um conselho, uma recomendação. Tomemos, a título de exemplo, o "proêmio" do Conto III, da Primeira Parte: 
Que as donzelas obedientes, devotas e virtuosas, que por guardar sua honra se aventuram a perigo de vida, chamando por Deus, ele lhes acode. Trata de uma donzela tal, que é digno de ser lido (p.10)

Esse formato prevalecerá, sem exceção, em todos os contos. Se bem que essa característica seja própria do gênero - o de exemplos -, nota-se que o realce se dá ao papel doutrinário do próprio autor.

IV. Os ditos, provérbios, exemplos, máximas são, também sem exceção, uma clara demonstração de que, com eles, o narrador pretende ensinar. Apesar de compilados do popularesco ou das diversas culturas de que se apropria, a voz que está por trás dos apotegmas é a do narrador analítico, que daqueles recursos se vale para pregar.

V. O narrador assume a primeira pessoa gramatical, seja do singular, seja do plural, para fazer-se presente. Esse é o recurso mais extensamente utilizado. Citemos alguns exemplos:

Foi este dito muito notado e, a meu entendimento, deve ser recomendado... (Conto IV, Primeira Parte, p. 19)

O qual, a meи parecer, é grande exemplo para Prelados, os quais devem ter tanto cuidado dos súbditos... (Conto VIII, Primeira Parte, p. 30)

Assim nós, pois, entendemos que a fazenda, os filhos, privança e honras da terra não hão-de durar para sempre e são quebradiços como vidro. (Conto XII, Primeira Parte, p. 52)

É notória a intenção de Trancoso ao empregar essas formas gramaticais. É o próprio autor que, através de sua autoridade, quer dar seu testemunho a favor das Virtudes que prega pelos exemplos.

VI. Em algumas histórias, Trancoso usa o recurso do encaixe (mise-en-abyme), quando quer ressaltar não só a própria narrativa, como quando pretende, pela digressão da ação precedente, ressaltar o ensinamento embutido no seu relato. O Conto XV, da Primeira Parte, é rico desse recurso. À página 67, interrompe a narrativa para conversar com os filhos e filhas, epigrafando o encaixe que motiva a narrativa principal:

Aqui notem, filhos e filhas, quanto lhe convém estar à obediência dos pais e não aceitar casamento sem concelho e bênção, por que não caiam em sua desgraça e, miseráveis, venham a seus irmãos pedir socorro, como este fez que, vendo-se o mais velho em tanta miséria...

A seguir, relatará os périplos por que passa o irmão deserdado, por ter-se casado sem a licença do pai. Para dar ênfase ao seu sofrimento por ter desobedecido ao pai, na evolução da trama, vai encaixando pequenas histórias que vão dando pretextos ora para o ensinamento, ora para o desfecho feliz. Insere, à página 70, um trecho sobre a ganância da esposa do irmão menor ao desencadear a desgraça do irmão deserdado:

Consideremos agora como, por fazer a vontade a sua mulher, este homem rico persegue a seu irmão pobre. Ó mundo! Ambos são filhos de um pai e de uma mãe e um vai tão abatido e outro tão exalçado e o pior é que o mais velho, a pé, e o mancebo na sela, de maneira que por interesse contendem, levando o rico ao pobre quase a rasto(s).

Os exemplos de encaixe neste conto, com a intenção que anteriormente citamos, são muitos: uma grávida perde o filho no ventre, pela vontade que passa de comer a cebola assada do irmão de seu marido; o caso da tentativa daquele irmão de salvar um cavalo de 
afogamento, quando, ao pretender ajudar um mercador, acaba prejudicando, pois, ao puxar o animal pelo rabo, este sai-lhe à mão - uma digressão de cunho cômico; além de outros encaixes em que, depois de resolvido o caso junto ao Regedor, os papéis se mostram invertidos e o pobre deserdado sai vitorioso, pelas argumentações retóricas de que se vale o próprio Regedor, provando ter sido o irmão desgraçado vítima e não causador dos incidentes. Ressalte-se, o que é mais notório, que cada encaixe vem precedido da intervenção do narrador com uma exclamação de espanto, relato de uma nova história e conclusão com um conselho ou ensinamento.

VII. Outro tipo de interveniência interessante que usa Gonçalo Fernandes é o do diálogo ou exposição da personagem quando vai relatar fatos. Utilizando o discurso do Outro - no caso, o da personagem - Trancoso se imiscui na personalidade do discursante e, através dele, transmite suas ideias. O recurso de que faz uso é próprio da Retórica: uma expositio eivada de exemplos, analogias, saudações à Providência ou sabedoria dos que estão numa escala superior e que, por isso, são os regentes dos súditos. Um bom exemplo é o conto maravilhoso de número I, da Terceira Parte. É o caso de um fidalgo, que na verdade era o Príncipe abandonado quando criança, trocado pela ação de personagens más por outro, que, no desenrolar da narrativa, revelar-se-á covarde. Quando vai defender-se da ação de ter afrontado o falso Príncipe, o nobre fidalgo utiliza um discurso, longuíssimo, para mostrar qual era sua verdadeira identidade. Vale uma pequena mostra desse discurso:

- Muito alto e poderoso Rei e senhor nosso, como quer Deus Nosso Senhor, em tudo seja
(como é) perfeito e justo, todavia sua misericórdia é sobre todas suas obras, e como pai mise-
ricordioso, ainda que algumas vezes nos castiga, sempre o faz para nosso bem. E se nos dá, a
nosso parecer, um mal, é para nos livrar de outro maior. E assim eu confio em Ele, que é
benigno Senhor, que, ainda que V. A. está menencório, a seu parecer, com razão, se me ouviu
diante destes fidalgos e letrados, com ânimo desapaixonado, sem outra prova senão minhas
palavras... (pp. 233-34)

Perceberá o leitor atento que o discurso é o do narrador, e o eu que se declara é aquele narrador que nas alusões e exemplos, expondo os ensinamentos e provérbios, pretende valer sua opinião sobre as intenções que levaram às más ações dos antagonistas.

\section{Conclusão. Gonçalo Fernandes Trancoso e a tradição doutrinária em Portugal}

O estudioso dos Contos de Trancoso, João Palma-Ferreira, declara que

o Renascimento, em Trancoso, é (...) ainda o de quase impossível 'ponto de cisão' entre a mentalidade arcaica, exausta e atacada por todos os ângulos e a mentalidade nova que se equilibra já na primeira fase do seu grande triunfo à escala universal. Não devemos esquecer que, nos seus princípios, tanto as estruturas morais da Reforma como as da Contra-reforma estão profundamente impregnadas de motivações medievais. Esse movimento ou ponto de cisão ainda latente é difícil de caracterizar cronologicamente e impossível dizer-se quando um homem deixa de ser medieval e já é renascentista; quando uma doutrina perde todo o caráter da Idade Média e se apresenta já como uma conquista do Humanismo (PALMA-FERREIRA, 1974, p. LXXIVLXXV).

No levantamento que fizemos dos aspectos estruturais dos Contos e Histórias de Proveito \& Exemplo, pudemos constatar o que acima afirma o estudioso português: Gonçalo Fernandes Trancoso é um autor renascentista que ainda cultiva o que se pregava na Idade 
Média. Pudemos perceber que, se Trancoso inova e é reconhecido como o primeiro contista da língua portuguesa, assim o fez porque o formato que dá aos seus textos é já o de um gênero literário diferente, que se convencionou chamar conto. E isso faz carregando as narrativas de um estilo que mescla formas arcaicas às inovadoras, dando à obra um aspecto que pretende já revolucionar. Em outras palavras, Trancoso cria um texto renascentista, travestido de roupagens medievais, com sabor de ineditismo e, ao mesmo tempo, de conservadorismo.

Quanto ao nível temático, ao ler Gonçalo Trancoso, deparamo-nos com um autor humanista que entende ser o novo homem o responsável por seu destino ${ }^{14}$, como o provam os muitos contos em que o autor narra a saga do herói em busca, ele mesmo, de reparar suas angústias, ao contrário do herói medieval, que, mesmo em busca de aventuras temporais, sempre se depara com a intervenção divina, a guiá-lo no caminho do bem. Contudo, essa interveniência não é de todo abandonada em Trancoso. Caso o fosse, não se justificaria sua obsessão pela denúncia aos novos costumes, através da pregação, de forma didática, de uma moral religiosa, própria dos séculos XII-XIII, e outra, social, própria do século XIV ${ }^{15}$. A propósito dessa moral, muito do que se encontra no Leal Conselheiro, de D. Duarte - um manual de condutas virtuosas que deveria guiar o homem nobre português - encontramos nos Contos de Gonçalo Fernandes. Contudo, agora, em um novo contexto, principalmente quando quer Trancoso ampliar sua pregação daquelas virtudes não apenas para determinada classe social, a nobre, mas sim para todos os novos homens do século XVI.

\section{REFERÊNCIAS}

BAKHTIN, Mikhail. A Tipologia do Discurso na Prosa. In: COSTA LIMA, Luiz (org.). Teoria da Literatura em suas fontes. Rio de Janeiro: Francisco Alves, 1975. p. 462-484.

BATANY, Jean. Escrito/Oral. In: LE GOFF, Jacques \& SCHMITT, Jean-Claude. Trad. Lênia Márcia Mogelli. Dicionário Temático do Ocidente Medieval. Bauru: EDUSC, 2002, p. 383-395. BOCCACCIO, Giovanni. Trad. Torrieri Guimarães. Decamerão. São Paulo: Abril Cultural, 1979. BRAGA, Teófilo. Contos Tradicionais do Povo Português. Lisboa: Publicações D. Quixote, 1994a. Vol. I.

Vol. II.

Contos Tradicionais do Povo Português. Lisboa: Publicações D. Quixote, 1994b.

CORTÁZAR, Julio. Alguns aspectos do conto. Trad. Davi Arrigucci Jr. In: Valise de Cronópio. São Paulo: Perspectiva, 1974, p. 147-164.

DIAS, Aida Fernanda. Cancioneiro Geral de Garcia de Resende. A Temática. Maia: Imprensa Nacional-Casa da Moeda, 1998.

FINNAZI-AGRÒ, Ettore. A novelística portuguesa do século XVI. [Venda Nova - Amadora]: 1978. Biblioteca Breve. Série Pensamento e Ciência, vol. 24.

LEBRUN, François. As Reformas: devoções comunitárias e piedade pessoal. In: ARIÈS, Philippe \& DUBY, Georges. História da Vida Privada. Da Renascença ao Século das Luzes. Trad.

\footnotetext{
${ }^{14}$ Luís André Nepomuceno discorre sobre isso: "E reside justamente aí o plano filosófico central da obra: a aceitação do destino e das adversidades da vida, com resignação e determinação ajustadas pelo tempero das virtudes estoicas. É certo que muitos outros temas mais leves ou eventualmente jocosos acodem à imaginação do autor, mas o peso da revelação moral dá as mãos ao leitor pelas três partes da obra" (NEPOMUCENO, 2017a, p. 2).

${ }^{15}$ Essa distinção cronológica não é tão clara como a colocamos. A marcação dos séculos a que aludimos deve ser tomada apenas como parâmetro didático. Contudo, André Vauchez nos socorre quanto a esse didatismo, principalmente quando se refere ao século XII: "O renascimento intelectual fez-se acompanhar de uma renovação do interesse pela vida interior. Ou melhor - porque se trata aqui de distinções demasiado modernas -, quando foi alargada a estreita franja daqueles que, na sociedade ocidental, acediam à vida do espírito, daí resultaram, em simultâneo, progressos no plano cultural e um aumento do nível das aspirações religiosas." (VAUCHEZ, 1995, p. 201-2).
} 
Hildegard Feist. São Paulo: Companhia das Letras, 1991, Volume 3, p. 71-111.

MOISÉS, Massaud. A Criação Literária. Introdução à Problemática de Literatura. São Paulo: Ed. Melhoramentos, 1967.

. O Conto Português. São Paulo: Cultrix, 1995.

MONGELLI, Lênia Márcia (Coord.). A Literatura Doutrinária na Corte de Avis. São Paulo: Martins Fontes, 2001.

NEPOMUCENO, Luís André. O maravilhoso medieval nas narrativas de Gonçalo Fernandes Trancoso. In: Revista Chilena de Estudos Medievais, no. 12, 2017 a.

. O mal que se repara: violência contra as mulheres nos contos de Gonçalo Fernandes Trancoso. In: Aletria, v. 27, no. 1, $2017 \mathrm{~b}$.

PAIVA, Dulce de Faria. História da Língua Portuguesa. II. Século XV e meados do século XVI. São Paulo: Ed. Ática, 1988.

PALMA-FERREIRA, João (Prefácio, leitura de texto, glossário e notas). In: TRANCOSO, Gonçalo Fernandes. Contos e Histórias de Proveito \& Exemplo. Lisboa: Imprensa Nacional- Casa da Moeda, 1974.

PIGLIA, Ricardo. Teses sobre o Conto. In: O laboratório do Escritor. Trad. José Marcos Mariani de Macedo. São Paulo: Iluminuras, 1994, p. 37-42.

PROPP, V. I. Morfología del Cuento. Buenos Aires: Juan Goynarte-Editor, 1972.

RUGGIERI, Jole. Il Canzoniere di Resende. Genève: Leo S. Olschki, S.A. Éditeur, 1931.

TODOROV, Tzvetán. Os Homens Narrativas. In: As Estruturas Narrativas. Trad. Leyla Perrone-Moisés.. São Paulo: Perspectiva, 1980a, p. 119-133.

. A Gramática da Narrativa. In: As Estruturas Narrativas. Trad. Leyla Perrone-

Moisés. São Paulo: Perspectiva, 1980b, p. 119-133.

TRANCOSO, Gonçalo Fernandes. Contos e Histórias de Proveito \& Exemplo. Lisboa: Imprensa Nacional- Casa da Moeda, 1974.

VAUCHEZ, André. A espiritualidade na Idade Média Ocidental - Séculos VIII-XIII. Trad. Lucy Magalhães. Lisboa: Editorial Estampa, 1995.

ZINK, Michel. Literatura(s). Trad. Lênia Márcia Mongelli. In LE GOFF, Jacques \& SCHMITT, Jean-Claude. Dicionário Temático do Ocidente Medieval. Bauru: EDUSC, 2002, p. 79-93. 